\title{
Guaranteed Employment and Universal Child Care for a New Social Contract
}

\author{
Jon D. Wisman and Aaron Pacitti ${ }^{1}$
}

The United States is falling behind many other rich nations on a broad spectrum of measures of the quality of life. These include social mobility, inequality, education, crime, health and longevity. Polls suggest that many Americans have not only lost their optimism concerning the future, but have become angry as well. This article sets forth the elements of a new social contract, one that would deliver substantial results almost overnight and which conforms to the traditional American values of the importance of work, that everyone should have a fair opportunity for upwards mobility, and the central importance of the family. This proposal is composed of two parts: The first is guaranteed employment, and where necessary, the retraining required to enable workers to successfully enter the regular workforce. The second is universal child care to give all parents the possibility of participating in the labor force. The article discusses in depth how these measures would reverse the relative decline in quality of life in America. It also reveals how, although these measures would be costly, their payoff for the economy would far offset the costs. [Article copies available for a fee from The Transformative Studies Institute. E-mail address: journal@transformativestudies.org Website: http://www.transformativestudies.org (C2018 by The Transformative Studies Institute. All rights reserved.]

KEYWORDS: Guaranteed Employment, Retraining, Social Costs of Unemployment, Child Care.

\footnotetext{
${ }^{1}$ Jon D. Wisman, Ph.D., is Professor of Economics at American University in Washington, D.C. where he teaches a graduate course in the history of economic thought methodology and various undergraduate courses. He has published in a wide variety of journals and books, and edited Worker Empowerment: The Struggle for Workplace Democracy. His most recent published work has addressed the potential for employer of the last resort programs and the role of inequality in generating economic crises and environmental devastation. During 2002, he served as President of the Association for Social Economics. Address correspondence to: Dr. Jon D. Wisman, Department of Economics, American University, Washington, D.C. 20016; Tel. 202-885- 3158; e-mail: jdwisma@american.edu.

Aaron Pacitti, Ph.D., is the Douglas T. Hickey Chair in Business and an Associate Professor of Economics. His research and teaching focus on macroeconomics, unemployment, employment insecurity, and inequality. Aaron's research has been published in the Eastern Economics Journal, the Journal of Economic Issues, the Journal of Post Keynesian Economics, Challenge, and the Forum for Social Economics. He is currently developing a survey to collect quantitative data on job quality with the Siena Research Institute. His work on the rise of the service sector and the slowing pace of economic recoveries has been cited by the Congressional Budget Office and was featured in the Washington Post. Aaron is also a regular contributor to the Huffington Post.
} 